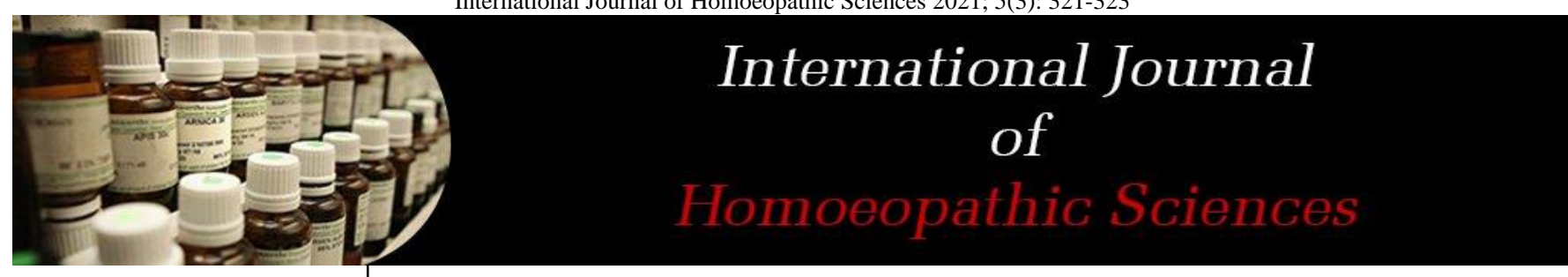

E-ISSN: 2616-4493 P-ISSN: 2616-4485 www.homoeopathicjournal.com IJHS 2021; 5(3): 321-323 Received: 22-05-2021 Accepted: 24-06-2021

Dr. Alex A Volinsky Ph.D., Department of Mechanical Engineering, University of South Florida, 4202 E. Fowler Ave., Tampa FL, USA

Dr. Sergey V Gunter Ph.D., Laboratory of Medical Alloys and Shape Memory Implants, National Research Tomsk State University, 36 Lenin Ave., Tomsk, Russia
Corresponding Author: Dr. Alex A Volinsky Ph.D., Department of Mechanical Engineering, University of South Florida, 4202 E. Fowler Ave., Tampa FL, USA

\section{Two cases of isopathic and homeopathic treatment of coronavirus disease 2019}

\author{
Dr. Alex A Volinsky and Dr. Sergey V Gunter
}

DOI: https://doi.org/10.33545/26164485.2021.v5.i3e.442

\begin{abstract}
Two cases of COVID-19 disease treatment are reported using a combination of isopathic and homeopathic approaches. Autonosodes made from sputum, nose discharge, and ear wax along with Mercurius Solubilis, Euphorbium, Rhus Toxicodendron, and Arsenicum Album homeopathic remedies were used. Treatment lasted two weeks and no complications were observed. After successful recovery both subjects had a large IgG antibodies count, demonstrating coronavirus immunity.
\end{abstract}

Keywords: coronavirus disease 2019, covid-19, isopathy, homeopathy, autonosode, mercurius solubilis, euphorbium, rhus toxicodendron, arsenicum album

\section{Introduction}

Coronavirus disease is caused by the SARS-CoV-2 (COVID-19) virus, which spread from Wuhan, China at the end of 2019. SARS stands for the severe acute respiratory syndrome. The estimated death rate from the highly contagious COVID-19 infection is $3 \%{ }^{[1]}$. Unlike previous epidemics, coronavirus was heavily covered by the mass media, spreading fear throughout the World. Many people died from complications associated with coronavirus. As a result, quarantine measures were implemented in most countries. The whole industry, including air travel, was severely affected by the new restrictions and policies. The whole situation with coronavirus is heavily politicized, and the long-term effects of the coronavirus epidemic are yet to be determined since it is still ongoing. Extreme lockdowns, social distancing, and quarantine measures might have stopped the virus spread in China [2] However, locking families in individual high-rise apartments may be ineffective, since sewage lines are exposed in China ${ }^{[3]}$, and viruses can spread through ventilation systems.

This paper describes isopathic and homeopathic treatment of two subjects with severe acute respiratory syndrome caused by the SARS-CoV-2 virus, which lasted two weeks without complications. In the summer of 2021, two males were infected by the SARS-CoV-2 virus at the same time and recovered in two weeks.

\section{Homeopathy and Isopathy}

The homeopathic method of treating diseases was developed and publicized by Samuel Hahnemann (1755-1843). It is based on the principle "let like cure like" [2]. The word Homeopathy in Greek means "like a disease". The treatment system is based on the six principles:

1. Similia similibus curentur, let like cure like

2. Minimum dose

3. Potentized remedy

4. One homeopathic remedy is prescribed at one time

5. Provings using healthy people

6. The theory of miasms

The simillimum principle in homeopathy is that a homeopathic remedy is prescribed based on the symptoms that coincide with the poisoning symptoms of a substance in its undiluted form. In the undiluted form, the remedy causes certain symptoms in healthy people. For example, mercury and its compounds are extremely toxic ${ }^{[4]}$ and can cause severe symptoms ${ }^{[5]}$. The same can be said about poisonous arsenic ${ }^{[6]}$.

If patients experience symptoms similar to those caused by poisoning, the corresponding homeopathic remedy in diluted and potentized form can treat these symptoms. 
In addition to knowledge about the toxic effects of various substances, homeopathy is based on the results from provings, which are experiments using healthy volunteers who took the homeopathic remedy. An important rule of proving is to use only one remedy at a time. The materia medica, a list of symptoms caused by homeopathic remedies in healthy people, was written based on provings ${ }^{[7]}$.

Nosodes (from the Greek nosos, disease) are remedies prepared by dilution and potentiation of microorganisms, viruses, and pathological secretions. Isopathy (from the Greek iso, equal and pathos, disease) is derived from homeopathy in terms of diluted and potentiated pathogens, however, their applications are different. In homeopathy like cures like, while in isopathy diluted and dynamized pathogens treat the disease that they cause when undiluted. German veterinarian Wilhelm Lux has successfully treated scabies and glanders in animals with nosodes. Lux used a 30C scabies nosodes prepared from the blood of animals with scabies. For the treatment of glanders, Lux used nosodes prepared from the secretions of the nasal mucosa of sick animals. The reason Lux started using nosodes was that he could not find homeopathic remedies for treating these diseases in animals ${ }^{[8]}$.

American homeopath Constantine Hering also used nosodes, but not based on the isopathic principle like Lux, but rather on the simillimum principle using the theory of miasms ${ }^{[9]}$. Isopathy implies the principle of identity when, for example, the SARS-CoV-2 virus nosode prepared from the body secretions cures it.

Autonosodes are prepared from the patient's secretions and are used according to the isopathic principle for the treatment of diseases, and not according to the simillimum principle. The materia medica of nosodes describes various symptoms and methods of using nosodes ${ }^{[10]}$. In certain cases, nosodes can exacerbate the disease, therefore, additional specific drainage therapy with homeopathic remedies is necessary.

\section{Isopathic and homeopathic treatments}

Two males, 41 (BMI 30) and 48 (BMI 29.5) years old were infected with the SARS-CoV-2 virus and had similar symptoms. During the first week, there was severe back pain, which was alleviated by motion or taking a shower, along with extreme fatigue. The SARS-CoV-2 diagnosis was confirmed by the positive IgG antibodies tests after recovery.

\subsection{Isopathic treatment}

During the first week, $4 \mathrm{~K}$ autonosode made from sputum, nasal discharge, saliva, and ear wax was taken twice per day. The $4 \mathrm{~K}$ autonosode was made using the Korsakov preparation method in a plastic bottle. An instructional video about nosode preparation can be found in reference [11]. Sputum, nasal discharge, saliva, and ear wax were placed in a paper napkin, which was folded and placed in a glass of water. About $50 \mathrm{ml}$ of this water was poured into a $500 \mathrm{ml}$ empty plastic bottle. Pure water was added to the bottle to fill it $75 \%$ by volume. The water in the bottle was successes 10 times, which completed the first cycle. Then water was poured out of the bottle completely. The bottle was filled again with fresh water to $75 \%$ of its volume and successes 10 times, which completed the second cycle. This was followed by the third and fourth cycles, resulting in the $4 \mathrm{~K}$ autonosode remedy.
The subjects were not aware at this point that they had COVID-19. During the second week, the senses of smell and taste were lost, suggesting SARS-CoV-2 virus infection. During the second week, isotherapy was complemented with two times per day intake of the homeopathic drainage remedies described in the next section.

\subsection{Homeopathic treatment}

Five granules of each commercially produced remedy were dissolved in $250 \mathrm{ml}$ of $40 \%$ alcohol and succussed 10 times. These remedies were Mercurius Solubilis 6X, Euphorbium 6X, Rhus Toxicodendron 6X, and Arsenicum Album 6X. 50 $\mathrm{ml}$ of alcohol with diluted granules were added to a $500 \mathrm{ml}$ water bottle and succussed 10 times. This water $(50 \mathrm{ml})$ was taken twice a day, in the morning and the evening. After a week of taking these remedies (two weeks total), the SARSCoV-2 virus symptoms subsided, signifying successful recovery.

\section{Discussion}

The homeopathic use of nosodes is much broader than in isopathy. For example, the Tuberculinum nosode prepared from the patient's secretions containing the pathogens of the tuberculous pathological process cures not only tuberculosis itself but can be used for severe dry cough, as well as nervousness and anxiety. Nosodes prepared from various allergens have been successfully used to treat allergy symptoms ${ }^{[12]}$, and the nosode made from tonsil stones cured chronic tonsillitis ${ }^{[13]}$. Isopathy in combination with homeopathy is beneficial for treating the human herpes simplex virus symptoms ${ }^{[14]}$, which inspired this study.

After about a month from recovery, both subjects had IgG antibodies tests done. In one case, the antibodies count was 185.9 BAU/ml, and in the other it was $67.5 \mathrm{BAU} / \mathrm{ml}$, proving that both subjects were infected with the SARS$\mathrm{CoV}-2$ virus and recovered successfully.

\section{Conclusions}

The paper describes two cases of successful treatment of the SARS-CoV-2 virus symptoms using isopathic and homeopathic methods. Autonosode in combination with Mercurius Solubilis, Euphorbium, Rhus Toxicodendron, and Arsenicum Album homeopathic remedies cured the SARS symptoms in two weeks.

\section{Acknowledgments}

The authors thank Dr. Vladimir Gavrilovich Marchenko for the selection of drainage homeopathic remedies and advice, and Dr. Elena Vladimirovna Marchenko for valuable discussions. The authors acknowledge support by the grant from the Government of the Russian Federation No. 220 of 09 April 2010 (Agreement No. 075-15-2021-612 of 04 June 2021).

\section{References}

1. Severe Acute Respiratory Syndrome (SARS), World Health Organization, https://www.who.int/healthtopics/severe-acute-respiratory-syndrome

2. China's Successful Control of COVID-19, T. Burki, Lancet 2020;20(11):1240-1241. Doi: https://doi.org/10.1016/S1473-3099(20)30800-8

3. Why China Stinks. Deficiencies in Plumbing and Ventilation Systems in China, A.A. Volinsky, International Journal of Civil Engineering and 
Technology (IJCIET) 2020;11(7):16-20.

4. The Toxicology of Mercury, L.A. Broussard, C.A. Hammett-Stabler, R.E. Winecker, J.D. Ropero-Miller, Laboratory Medicine 2002;33(8):614-625. https://doi.org/10.1309/5HY1-V3NE-2LFL-P9MT

5. Health Effects of Exposures to Mercury, United States Environmental Protection Agency, https://www.epa.gov/mercury/health-effects-exposuresmercury

6. Acute and Chronic Arsenic Toxicity, R.N. Ratnaike, Postgraduate Medical Journal 2003;79(933):391-396. http://dx.doi.org/10.1136/pmj.79.933.391

7. Homeopathic Materia Medica, W. Boericke, http://www.homeoint.org/books/boericmm

8. Pathways of Homoeopathic Medicine, B. Blessing, Springer 2011.

9. Isodes, Nosodes and Sarcodes in Homoeopathy, https://www.homeopathy360.com/2017/05/08/isodesnosodes-and-sarcodes-in-homoeopathy-2/

10. Julian's Materia Medica of Nosodes with Repertory, $1^{\text {st }}$ Edition, O.A. Julian, B. Jain Publishers 2003.

11. How to Make Nosodes and Autonosodes, Instructional Video, https://youtu.be/nIHayHb-2Cg

12. Allergy Desensitization Based on Allergens Dynamization Method, A.A. Volinsky, International Journal of Homoeopathic Sciences Part D 2020;4(4):198-201.

13. A Clinical Case of Chronic Tonsillitis Treatment Using Homeopathy and Autonosodes, A.A. Volinsky, International Journal of Homoeopathic Sciences, Part C 2021;5(1):152-154.

14. A Clinical Case of Homeopathic and Isopathic Treatment of Human Herpes Simplex Virus, A.A. Volinsky, International Journal of Homoeopathic Sciences, Part C 2021;5(1):146-148. 